\title{
Research of Mixed Teaching Reform Model Based on SPOC
}

\author{
Xin Sui \\ College of Humanities and Sciences \\ Northeast Normal University \\ Changchun, 130117, P.R.China \\ suixin1997@126.com
}

\begin{abstract}
Massive Open Online Courses rapidly grow. SPOC is a small, restrictive online course that combines traditional classroom teaching with MOOC. SPOC can significantly improve the learning effect of MOOC. The mixed teaching model based on SPOC in colleges and universities is conducive to promoting the reform of teaching mode in higher education institutions, improving the quality of education and teaching, and improving the quality of personnel training. This paper puts forward the construction of a blended teaching model based on SPOC, and explores the teaching model. Through the analysis of the implementation effect of the curriculum reform, the mixed teaching reform mode based on SPOC is propitious to effectively improve the quality of teaching, and promote the teaching reform of information technology in Colleges and universities.
\end{abstract}

Keywords-SPOC; MOOC; traditional classroom; mixed teaching model

\section{INTRODUCTION}

MOOC is massive open online course, which means that any one of the learners' legumes can be registered and study. Coursera and other platforms launched the world-renowned universities MOOC courses, high-quality curriculum resources, and also provide with the corresponding certificate of completion to learners [1].

MOOC has not had a significant impact on the university's physical campus after sweeping the globe. As a result, the University of California, Berkeley and other prestigious schools began to explore a private, small-scale online open course SPOC. SPOC restricts learners and sets specific access conditions for learners. Reduced the size of the study to control the number of dozens of people to hundreds of people, to provide a better quality of teaching services [2].

\section{SiTUATION}

College Computer Basic Course is a general course for non-computer majors in colleges and universities. The aim is to enable students to master the basic knowledge of computer and information technology. Let students master the basic operating skills of computer. Improve students' quality and lay a good foundation for students to study independently and lifelong learning, in order to better services for professional.

Fund Project: The education of Jilin province "in 13th Five-Year" plan 2016 annual key project (Project No. ZD16071). Jilin Provincial Higher Education Association 2016 annual higher education research subject "Based on SPOC" Access Database Technology and Application "Mixed Teaching Mode" (Project No. JGJX2016B27) results. 2016 Jilin higher education reform research project "Based on MOOC+SPOC Flipped Classroom Teaching Mode" research results.
The university computer basic course of our mainly teaches the computer basic knowledge and the office automation software how to use. The emphasis is to train the student the actual operation ability. With the continuous progress of society, learning computer has already surpassed the level of technology, and has risen to the level of modern social culture. The original teaching method cannot meet the students' actual demand for computer ability.

The traditional teaching method is the teacher in the computer room teaching, after the lecture, decorates the students to carry out the corresponding practice. According to the completion of the students, further strengthen the key points or difficulties. This kind of teaching method avoids the "spoon" in the classroom, but the students seldom take the initiative to think in class. They depend excessively on the teacher, the ability of the student to solve the problem independently cannot get very good exercise.

\section{TEACHING DEsign BASED ON SPOC}

On the basis of SPOC mixed teaching mode, combining traditional classroom teaching with online learning, face-to-face teaching and virtual network learning are combined [3]. Upload instructional video to the online platform, students can do online courses under the course, and teachers can teach more difficult points of knowledge. This not only allows students to learn the relevant knowledge independently, but also communicate and discuss basic knowledge that the students have already mastered in class, so can further deepen and perfect the contents of the study.

The mixed teaching mode based on SPOC is the combination of online learning and classroom teaching, using teaching resources such as online teaching video, and implementing the teaching research of flip-class. The hybrid teaching model based on SPOC is composed of the following five links.

\section{A. Front-End Analysis Link}

SPOC Mixed learning has three important factors, namely: learning object, teaching content and teaching environment [4]. The analysis of the learning object mainly refers to the professional information and students' knowledge reserve. Grasp the analysis of the object of study, we can design different teaching content according to different professional characteristics, and make it more in line with the needs of different majors. The main content of teaching is to clarify the 
teaching objectives, syllabus, the key points and difficulties in the course of teaching. The students' learning environment is an important factor to give full play to the efficiency in mixed teaching, which mainly refers to the network teaching platform and the traditional classroom teaching environment.

\section{B. Course Design Phase}

The curriculum design mainly includes the knowledge unit video, the syllabus, the courseware, the exercise questions, the discussion questions and the test questions. Teachers can record and edit teaching videos by themselves. They can also make full use of the rich teaching resources on the MOOC platform [5].

When designing teaching resources, teachers should not only guarantee the fit between teaching resources and teaching knowledge points, but also enrich teaching resources as much as possible. It is helpful for students to understand and grasp the key and difficult points, and then improve the students' learning efficiency and effect [6].

In accordance with the needs of the students, teachers integrate the online teaching resources and physical resources. A micro - curriculum designed as a logical structure is uploaded to the network teaching platform. At the same time, other teaching materials are provided to students as an expanse of resources. Teaching resources play a vital role in the mixed teaching model. Whether the subsequent mixed teaching can be carried out smoothly depends on whether the design of teaching resources is reasonable [7].

\section{Pre-class Links}

The teacher needs to record the teaching video before class. Every teaching video is a knowledge point; the time is between 10 and 15 minutes. Teachers need to prepare teaching resources related to classroom teaching (courseware, phase test, discussion topics, etc.).

\section{Student Online Learning}

Students study online according to the learning task assigned by teachers, and they can complete autonomous learning by watching video. Students can adjust their learning progress according to their own understanding and acceptance degree, and also watch complex video parts repeatedly. In the process of watching the video, students can record their harvest and experience, and the existence of doubts. They can share them with other students. Students can also ask teachers questions online.

The teacher adjusts the classroom teaching content according to the questions raised by the students.

\section{E. Classroom Teaching Links}

Before class teaching, the teachers will test students. According to the students' test results, online questioning, communication discussion, etc., the teacher is targeted to explain the key points and difficulties. According to the results of students' test, online questioning, communication and discussion the teacher explained the key points and difficult points. The classroom teaching activities to help students to better complete the internalization of knowledge. The teacher can organize students to carry out research, collaborative learning, communication and interaction in class.
Teachers organize inquiry learning according to the problems raised by students before class. The problem of moderate difficulty enables students to solve problems independently and improve their ability of independent thinking as much as possible. We can choose the more difficult questions, let the students cooperate with each other, divide the students into groups, carry on the class discussion, and improve the ability to cooperate and solve the problem. Each member of the group should actively participate in the discussion of the problem, members exchange each other, and work together to solve the problem.

In the classroom, the students should report the content of the study, the teacher evaluates the students' learning effect, and the students also evaluate each other. Finally, the teacher should explain the emphases and difficulties of the teaching content of this lesson, summarize the learning effect of the students, and systematically summarize the content of the knowledge.

\section{F. Evaluation}

The evaluation link pays attention to students' learning effect, and combines process evaluation with summative evaluation.

The process of evaluation mainly includes the number of students' login teaching platform, the number of watching the video of the time, participation in the discussion. Combined with classroom teaching, team cooperation to complete the project situation, the performance and enthusiasm of classroom discussion, student self-assessment, and peer evaluation team members. Students make objective evaluation according to their mastery of knowledge, classroom performance and other aspects. Team members mainly evaluate of team members according to the mutual evaluation of students to participate in group discussion, actively participate in group activities and group contribution. This evaluation method helps to improve the enthusiasm of team members in cooperative learning, and helps students better participate in group learning activities. Teachers' evaluation of students is not to be ignored. The summative assessment of the main teachers is based on the results of the final examination of the candidates. Teachers give process evaluation and summative evaluation, each of them occupies a certain proportion, and finally gets the scores of students.

\section{ANALYSIS ON THE EFFECT OF CURRICULUM IMPLEMENTATION}

\section{A. Analysis of Learners' Satisfaction}

The students' satisfaction with this course is divided into five grades. A total of 200 students who participated in the SPOC blended teaching model were selected to conduct satisfaction surveys. The survey results were shown in Table I. 


\section{TABLE I. PERCENTAGE OF LEARNERS' SATISFACTION}

\begin{tabular}{|c|c|c|}
\hline Percentage of degree of satisfaction & Number & Percentage \\
\hline Very satisfied & 85 & $42.5 \%$ \\
\hline Satisfaction & 65 & $32.5 \%$ \\
\hline General & 13 & $6.5 \%$ \\
\hline Not satisfied & 22 & $11 \%$ \\
\hline Very dissatisfied & 15 & $7.5 \%$ \\
\hline
\end{tabular}

The percentage of each level is shown in Fig.1.

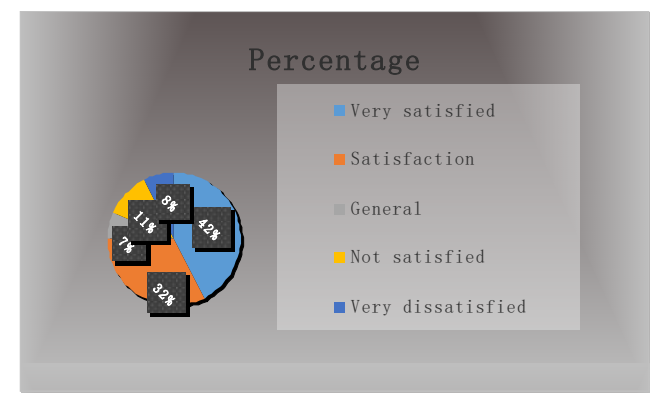

Fig. 1. The students' percentage of satisfaction

\section{B. An Analysis of The sSatisfaction of The Course of Teaching}

A questionnaire survey is conducted from the SPOC mixed teaching mode's curriculum objectives, teaching activities, teaching design, evaluation methods and other aspects, to reflect students' satisfaction with the whole course learning. A questionnaire survey was conducted among 300 students who participated in the curriculum reform of the SPOC mixed teaching model. The specific statistical results are shown in Table 2.

TABLE II. SATISFACTION OF THE PROCESS OF TEACHING

\begin{tabular}{|c|c|c|c|}
\hline Option & Satisfied & Commonly & Dissatisfied \\
\hline $\begin{array}{c}\text { Curriculum objectives: embody the } \\
\text { students as the center }\end{array}$ & $56.8 \%$ & $33.6 \%$ & $9.6 \%$ \\
\hline $\begin{array}{c}\text { Teaching activities: various forms } \\
\text { and rich content }\end{array}$ & $66.7 \%$ & $26.6 \%$ & $6.7 \%$ \\
\hline $\begin{array}{c}\text { Teaching design: conforming to the } \\
\text { cognitive structure of the learners }\end{array}$ & $56.9 \%$ & $38.9 \%$ & $4.2 \%$ \\
\hline $\begin{array}{c}\text { Curriculum evaluation: objective } \\
\text { evaluation of students' learning } \\
\text { effect }\end{array}$ & $52.9 \%$ & $32.8 \%$ & $4.3 \%$ \\
\hline
\end{tabular}

The goal of curriculum teaching is to reflect in teaching activities. Teachers use different teaching methods to make different learning objectives according to the actual situation of students and different needs. The mixed teaching model based on SPOC shows the learner centered and 170 students with a satisfactory attitude, accounting for $56.8 \%$ of the total number of students. 28 people are dissatisfied, accounting for $9.6 \%$ of the total.

The rich teaching resources in content and various forms are the characteristics of SPOC teaching. Teachers use the rich and quality teaching resources of the SPOC and platform to integrate a variety of rich learning resources to provide to students. From the data in the table, $66.7 \%$ of the students are satisfied, and the number of people satisfied was 200. It is dissatisfied with 20 people, accounting for $6.7 \%$ of the total.

Whether the curriculum evaluation objectively evaluates the students' school effect, only $4.3 \%$ of the students do not agree with the evaluation method. Most of the students agree with the evaluation methods used in this course.

\section{V.CONCLUSION}

Aiming at the university computer basic course, we adopted the mixed teaching mode of SPOC flipped classroom, which promoted the deep integration of online and offline teaching, and further promoted the reform of student centered learning and teaching methods. Optimizing the evaluation method of teaching, SPOC helps to improve the initiative of students learning, learning enthusiasm, but also enable teachers to more in-depth understanding of students in all aspects of information, help to better realize personalized teaching. The flipped classroom teaching mode has changed the students' learning mode and teaching mode of the teacher's. The students have the initiative to learn.

Deep learning model of SPOC, which can avoid the disadvantages of MOOC and traditional teaching, promote air plant resources in higher school physical MOOC teaching. This teaching mode can improve the students' innovative ability and improve the quality of higher education.

\section{REFERENCES}

[1] Li Ze, "After the era of MOOC: SPOC to change the traditional teaching," Software Guide (Educational Technology), 2017, (10), pp.66-68. (In Chinese)

[2] Yang Yi, "Professional computer application foundation SPOC hybrid teaching content design,” Computer Age, 2017, (10), pp.73-75. (In Chinese)

[3] Liang Fenglan, "Application and research of SPOC teaching mode based on MOOC resources,” Computer Times, 2017, (10), pp.53-55. (In Chinese)

[4] Sheng Lei, "Research on the flipped classroom teaching reform model based on MOOC+SPOC--Taking website design and construction course as an example," Educational Modernization, 2017,4 (39), pp.40-42. (In Chinese)

[5] He Bin, Cao Yang. "SPOC: based on MOOC teaching process innovation”, Chinese electrification education, 2015, (03): 22-29. (In Chinese)

[6] Chen Ran, Yang Cheng. "SPOC mixed learning model design research", China distance education, 2015, (05): 42-47+67+80. (In Chinese) 